Syntax Literate : Jurnal Ilmiah Indonesia p-ISSN: 2541-0849

e-ISSN : 2548-1398

Vol. 4, No. 9 September 2019

\title{
ANALISIS DAN PERANCANGAN ULANG SISTEM INFORMASI SEWA APARTEMEN ONLINE BERBASIS WEB STUDI KASUS DI PT. TIERRA PROPERTI INDONESIA (TIERRALOGY.COM)
}

\author{
Ponsen Sindu Prawito dan Fevy Mardhipta Trista Asri \\ Politeknik Praktisi Bandung \\ Email: ponsen@praktisi.ac.id dan feymardhiptagp@gmail.com
}

\begin{abstract}
Abstrak
Penelitian ini bertujuan menganalisis sistem yang sedang berjalan di PT. Tierra Properti Indonesia yang mana, pangsa pasarnya masih berpatok pada kalangan corporate atau petinggi-petinggi perusahaan. Seiring dengan analisis tersebut, penulis merancang sistem baru yang berpaku pada tenant atau orang yang akan menyewa apartemen, dan membuka pangsa pasar baru yaitu mahasiswa dan masyarakat (pegawai kantor \& khalayak umum). Perancangan tersebut bertujuan untuk memudahkan pengguna yang diharapkan adalah mahasiswa dan pegawai kantor untuk menemukan tempat tinggal di daerah-daerah tertentu yang merupakan sekitar kampus dan distrik perkantoran di DKI Jakarta.
\end{abstract}

Kata kunci: Sewa Apartemen, Properti, Kampus, Distrik Perkantoran, Mahasiswa, Pegawai Kantor, E-commerce, Web.

\section{Pendahuluan}

Memiliki tempat tinggal sudah menjadi kebutuhan pokok sejak dahulu. Selain sandang dan pangan, papan merupakan hal yang menjadi perhatian utama baik di desa maupun di kota. Kota pun menjadi tempat yang paling cepat berevolusi seiring dengan berkembangnya zaman, terutama dalam hal tempat tinggal. Dimana demand untuk rumah dan gedung terus menerus ada. Seiring berkurangnya lahan tanah, terobosan rumah susun pun berkembang menjadi lebih modern, contohnya adalah apartemen. Walaupun di Indonesia apartemen masih menjadi hal yang awam, namun tidak dapat dipungkiri bahwa demand dari apartemen kian meningkat.

Mencari apartemen bukan merupakan hal yang mudah. Sulitnya mencari apartemen yang cocok dengan lingkungan yang sesuai merupakan kendala yang sering dialami. Calon pembeli harus meluangkan waktu yang banyak untuk bisa menemukan apartemen yang sesuai dengan lokasi dan keinginan. 
Tierralogy merupakan perusahaan Start-up di bidang properti dalam bentuk “Apartment Renting" yang resmi berdiri sebagai Perseroan Terbatas pada tahun 2018. PT. Tierra Properti Indonesia, atau disingkat Tierralogy menyediakan sebuah layanan web yang dapat dimanfaatkan oleh pemilik apartement (Landlord) untuk memasarkan, mengiklankan dan mempublikasikan properti-propertinya yang berupa apartemen, yang kemudian dapat dilihat oleh calon penyewa (Tenant) yang ingin menyewa apartemen tersebut dalam jangka waktu singkat maupun jangka waktu yang panjang seperti bulanan maupun tahunan. Hal ini tentunya membuat pencarian apartemen lebih praktis, namun layanan web ini awalnya hanya terbatas untuk keperluan perusahaan dikarenakan pembagian daerah yang masih hanya disekitar distrik perkantoran di Daerah Khusus Ibu Kota Jakarta. Tierralogy telah memiliki sistem informasi sewa apartemen online dengan pangsa sebelumnya yaitu kalangan corporate (petinggi perusahaan). Karena target pasar pada sistem yang sedang berjalan terlalu khusus, banyak kelemahan dan ketidakefisienan sistem yang menjadi fokus utama penulis, seperti terlalu banyak pengajuan dan perbedaan tipe user yang tidak perlu, proses pemverifikasian akun tenant master yang memakan waktu, dan proses yang berbelitbelit. Hal-hal tersebut menjadikan proses transaksi menjadi berbelit-belit, lambat dan rumit.

Atas dasar permasalahan yang ditemukan, maka penulis melaksanakan penelitian dengan judul "Analisis dan Perancangan Ulang Sistem Informasi Sewa Apartemen Online Berbasis Web Studi Kasus di PT. Tierra Properti Indonesia (Tierralogy.com).”

\section{Metode Penelitian}

Dalam penelitian ini, penulis menggunakan metode pengembangan sistem dan teknik pengumpulan data sebagai berikut:

\section{Pengembangan Sistem}

Metode pengembangan sistem yang digunakan adalah metode waterfall.

\section{Teknik Pengumpulan Data}

Metode-metode yang digunakan dalam pengumpulan data adalah sebagai berikut:

a) Observasi 
Pengumpulan data dengan melakukan pengamatan secara langsung terhadap objek penelitian, dengan mencatat hal-hal penting yang berhubungan dengan judul laporan, sehingga diperoleh data yang lengkap dan akurat.

b) Wawancara

Pengumpulan data dengan cara melakukan komunikasi dan wawancara langsung dengan pihak-pihak terkait.

c) Studi Pusaka

Pengumpulan data dengan menggunakan atau mengumpulkan sumber-sumber tertulis, dengan cara membaca, mempelajari dan mencatat hal-hal penting yang berhubungan dengan masalah yang sedang dibahas guna memperoleh gambaran secara teoritis.

\section{Hasil dan Pembahasan}

\section{A. Functional Design (Rancangan Fungsional)}

\section{Use Case Diagram}

Berikut ini adalah Use Case Diagram yang penulis usulkan.

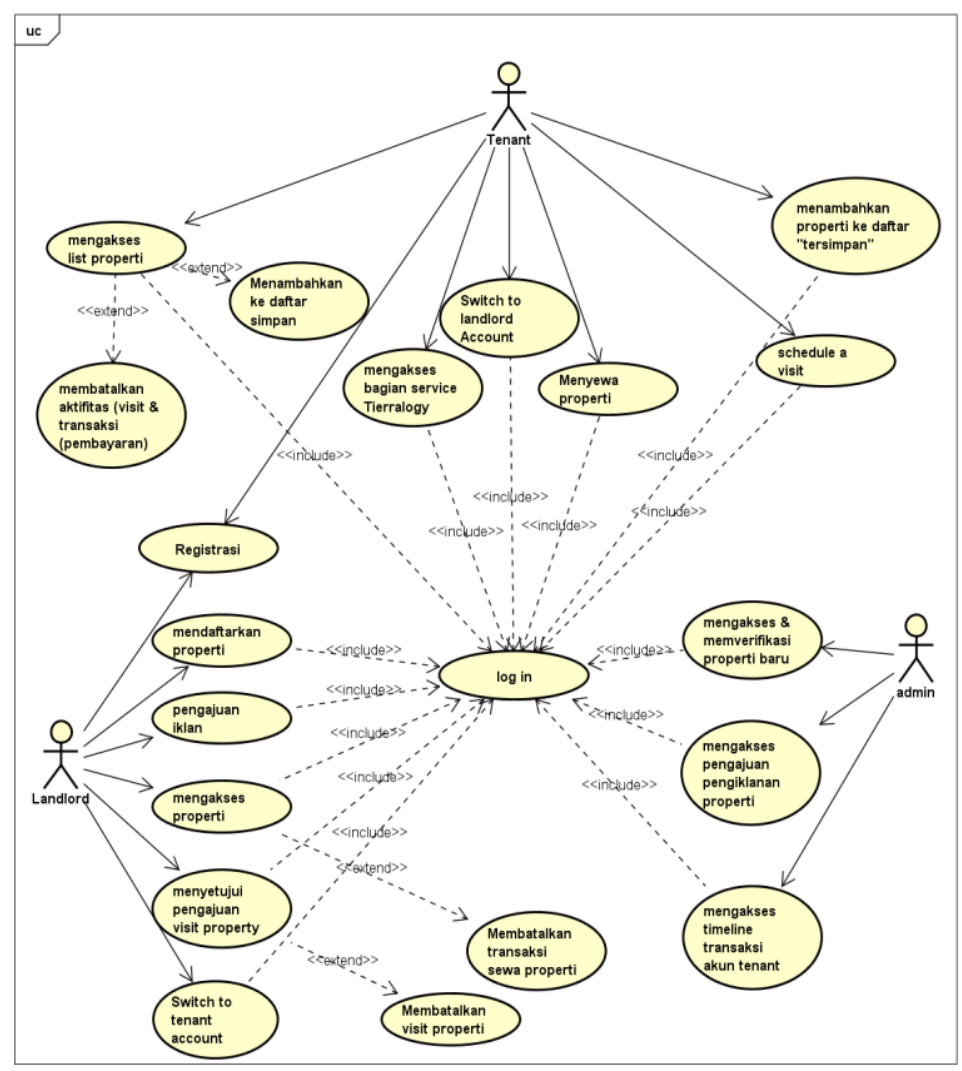

Gambar 1. Use Case Diagram Perancangan Sistem 


\section{Class Diagram}

Hasil rancangan Use Case Diagram tersebut penulis kembangkan menjadi sebuah Class Diagram. Berikut adalah class Diagram yang diusulkan penulis.

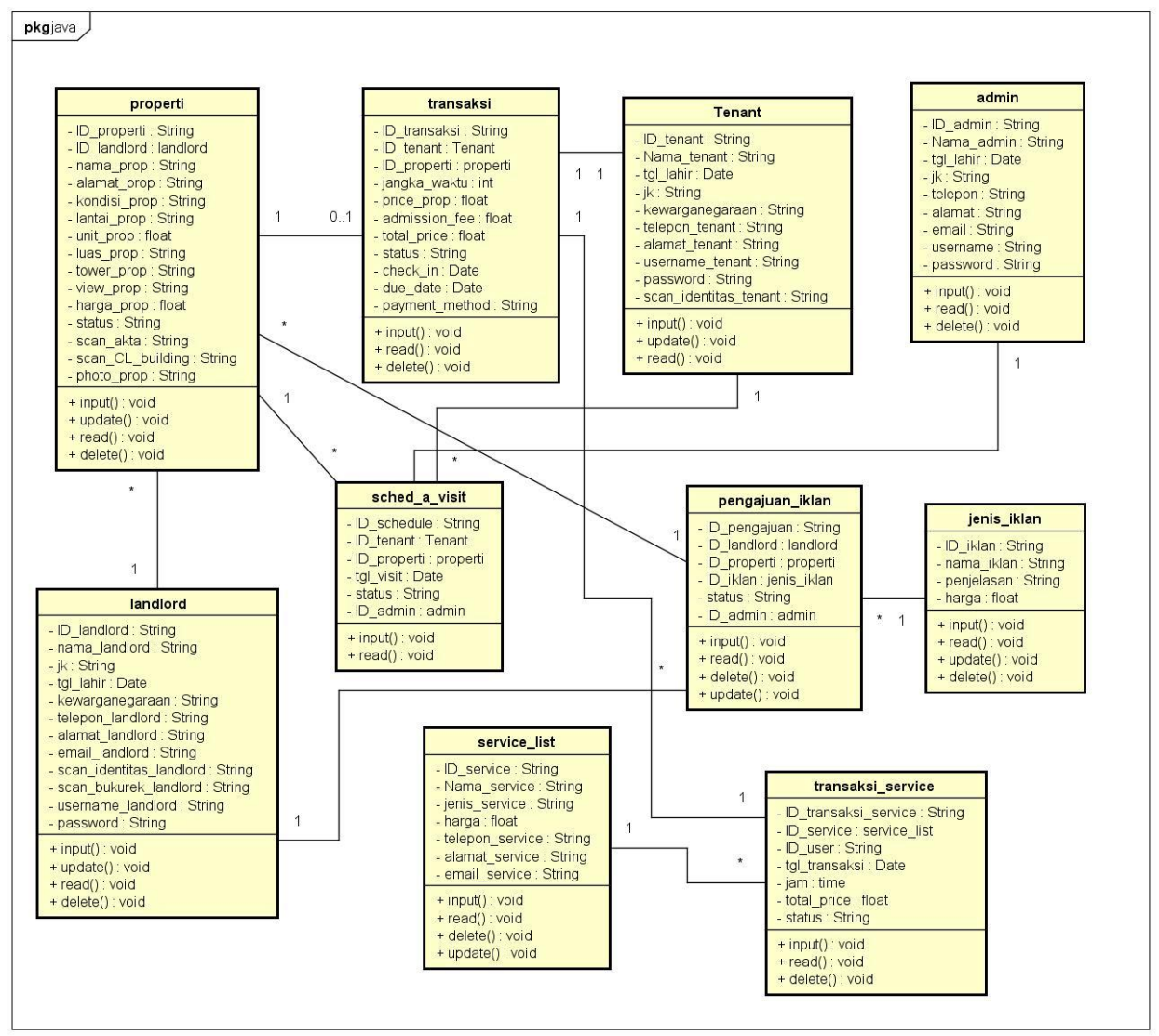

Gambar 2. Class Diagram Perancangan Sistem

\section{Activity Diagram}

1. Registrasi

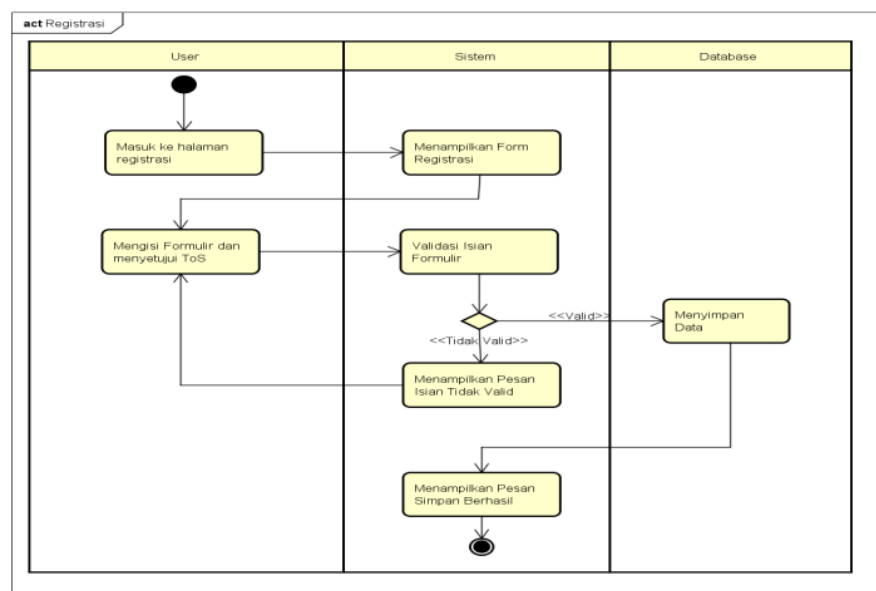

Gambar 3.1 Activity Diagram Registrasi 
Analisis dan Perancangan Ulang Sistem Informasi Sewa Apartemen Online

2. Login

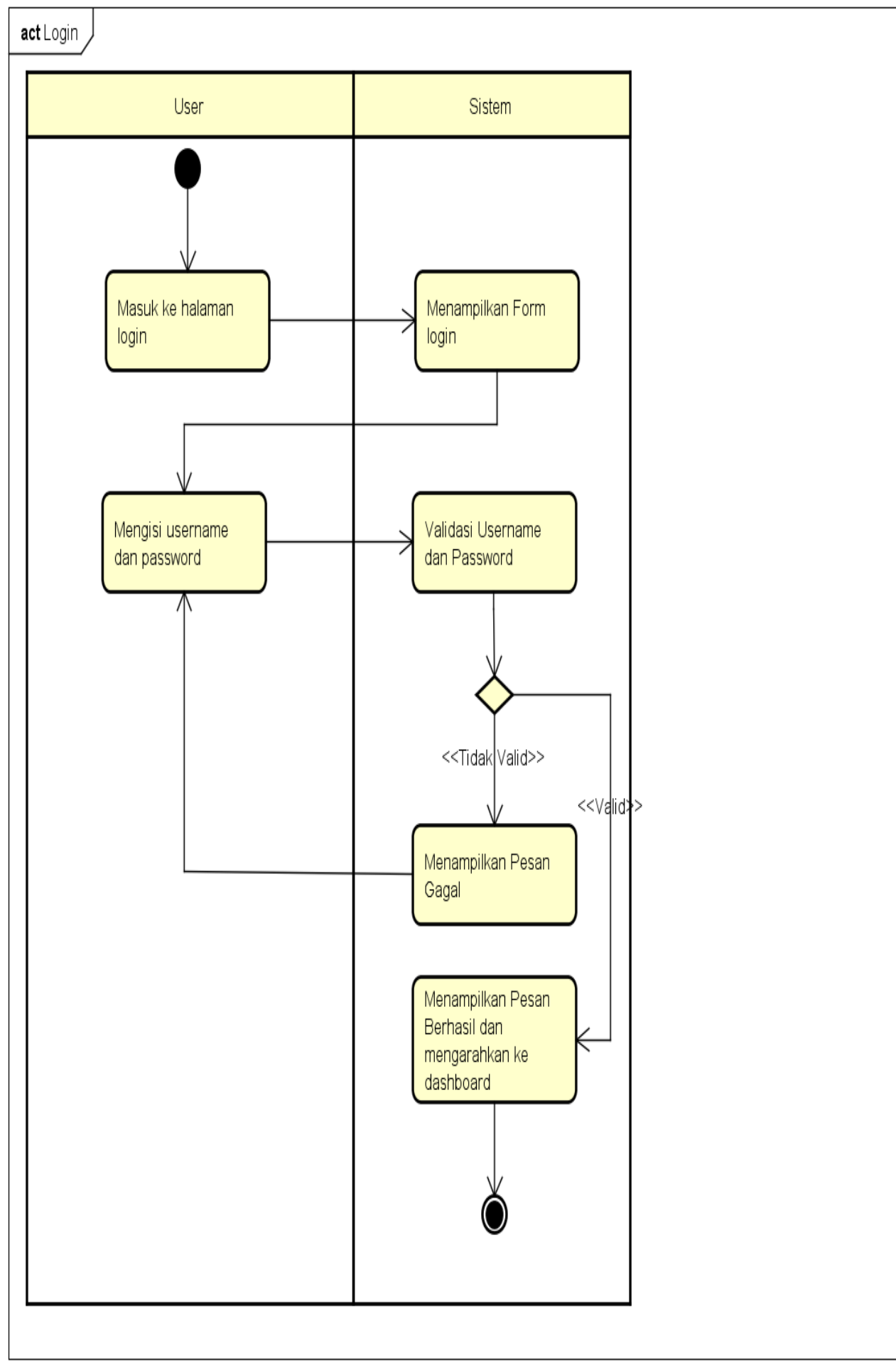

Gambar 3.2 Activity Diagram Login 
Ponsen Sindu Prawito dan Fevy Mardhipta Trista Asri

3. Mendaftarkan Properti(Landlord)

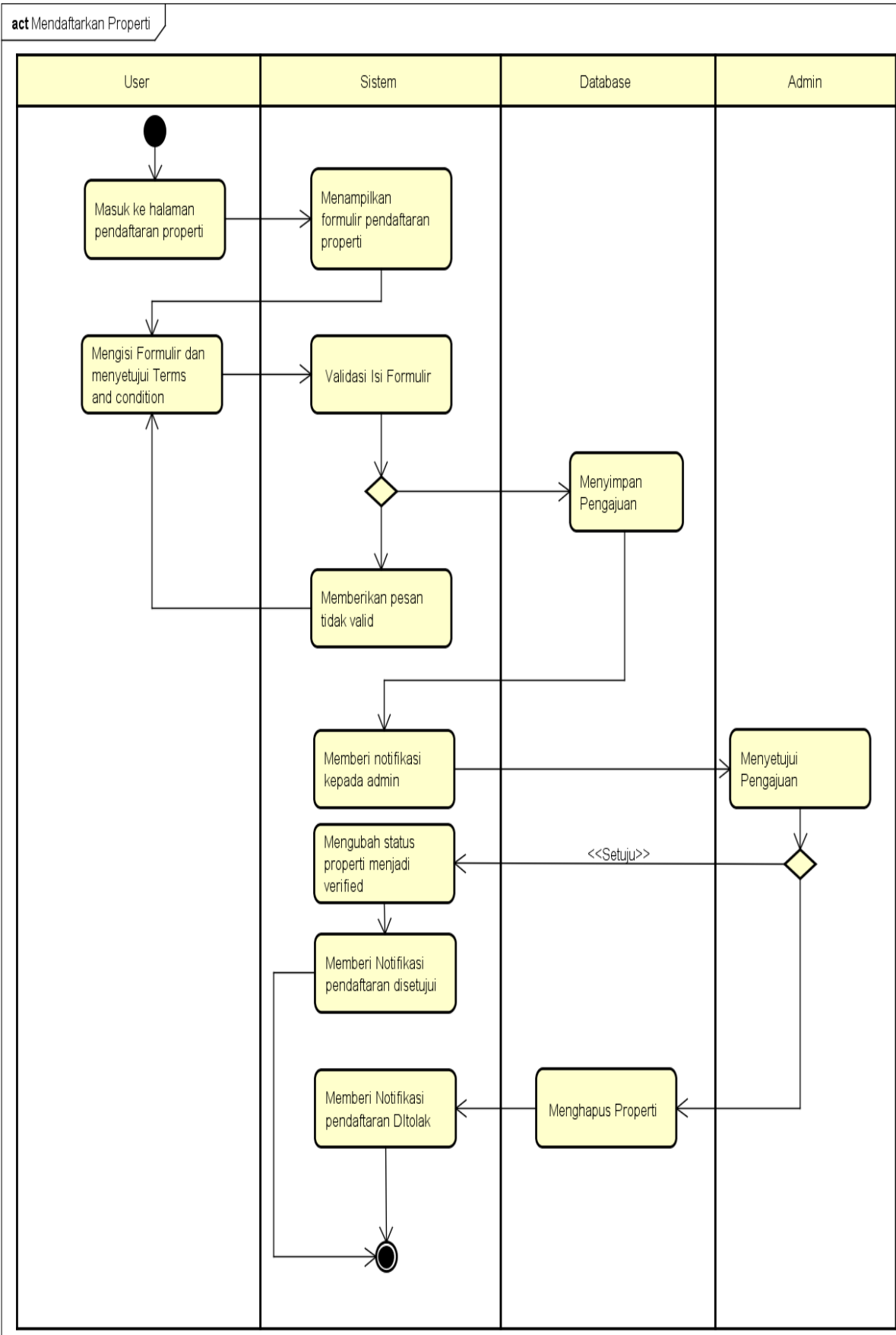

Gambar 3.3 Activity Diagram Mendaftarkan Properti 
Analisis dan Perancangan Ulang Sistem Informasi Sewa Apartemen Online

4. Pengajuan Iklan (Landlord)

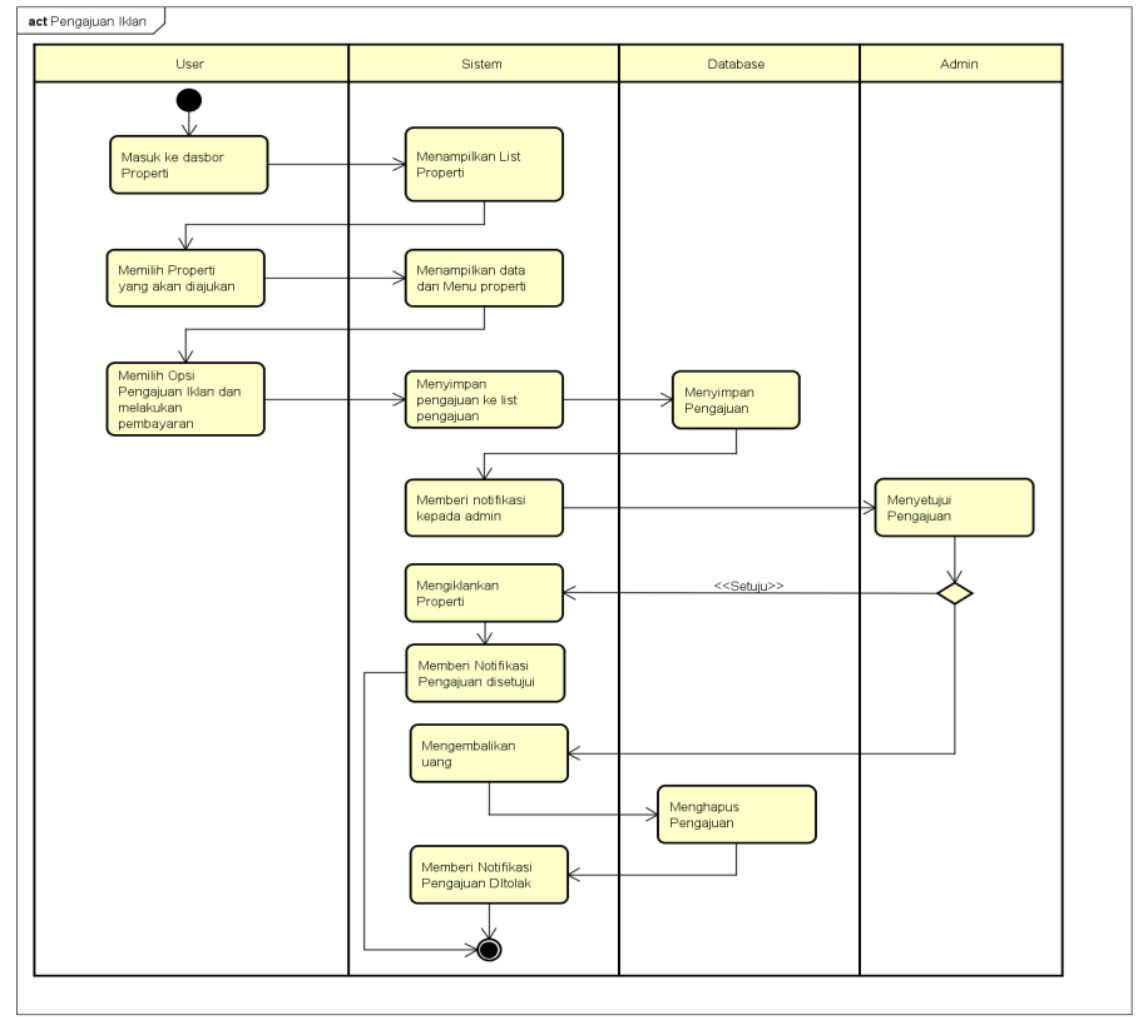

Gambar 3.4 Activity Diagram Pengajuan Iklan

5. Mengakses Properti(Landlord)

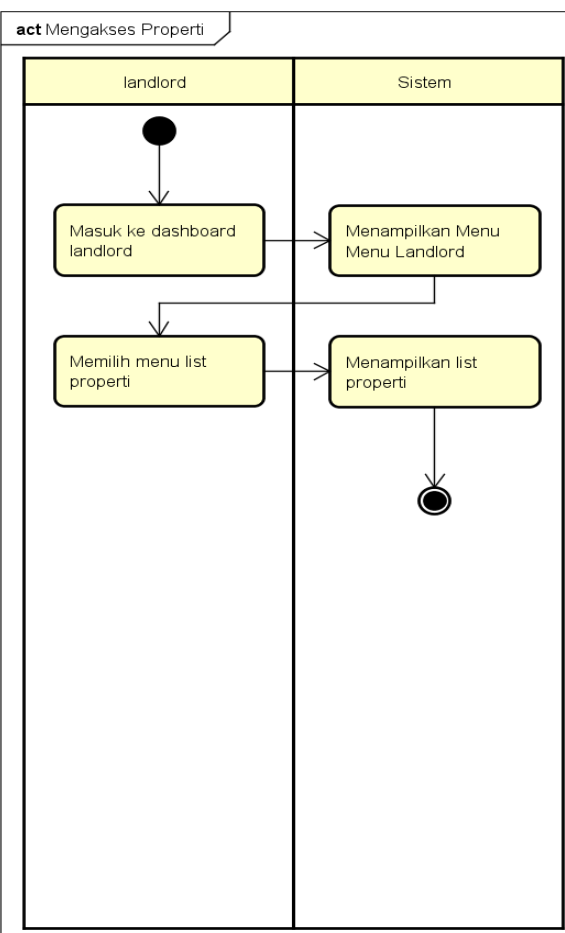

Gambar 3.5 Activity Diagram Mengakses Properti 
6. Menyetujui Pengajuan Visit Properti(Landlord)

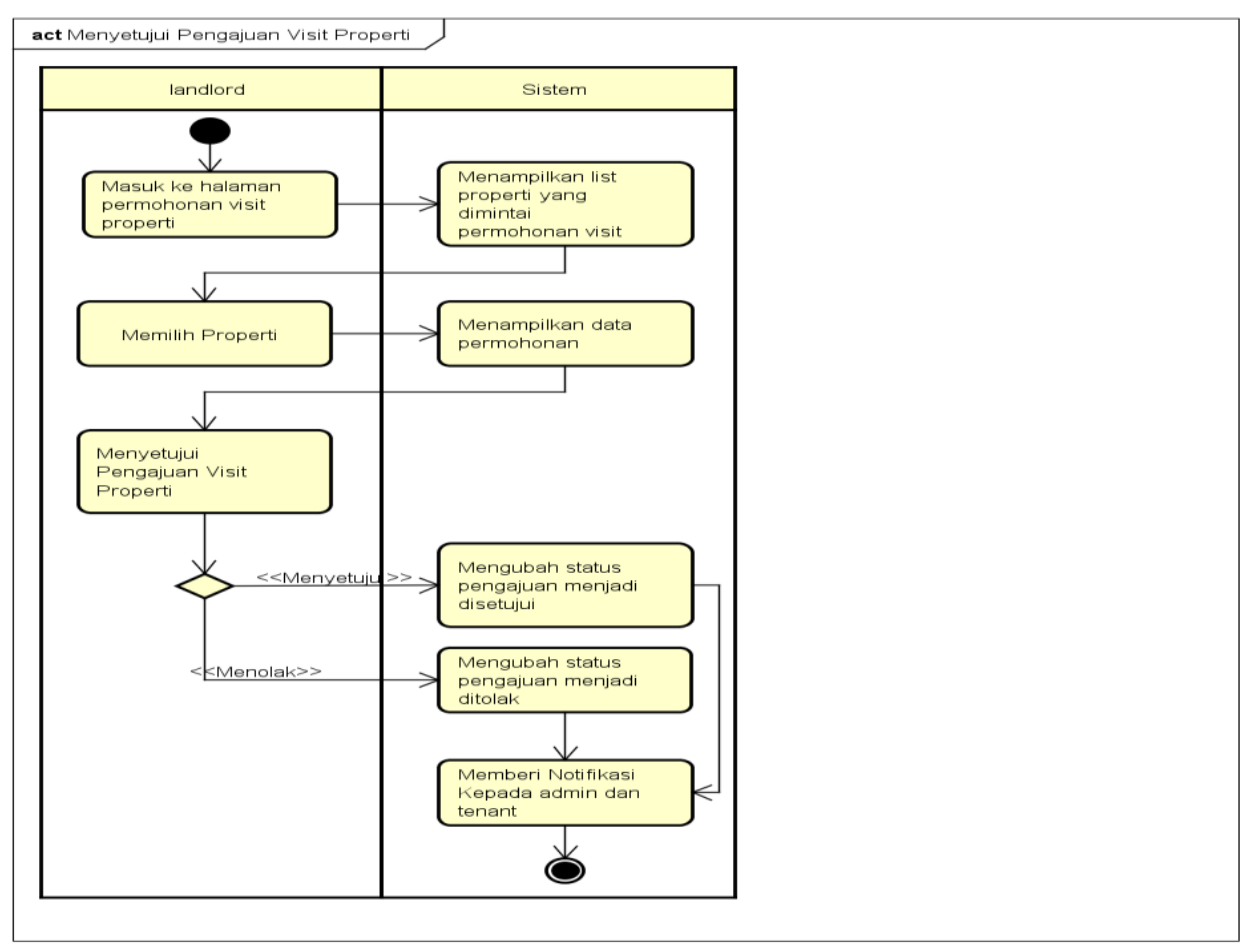

Gambar 3.6 Activity Diagram Menyetujui Pengajuan Visit Properti

7. Switch to Tenant Account(Landlord)

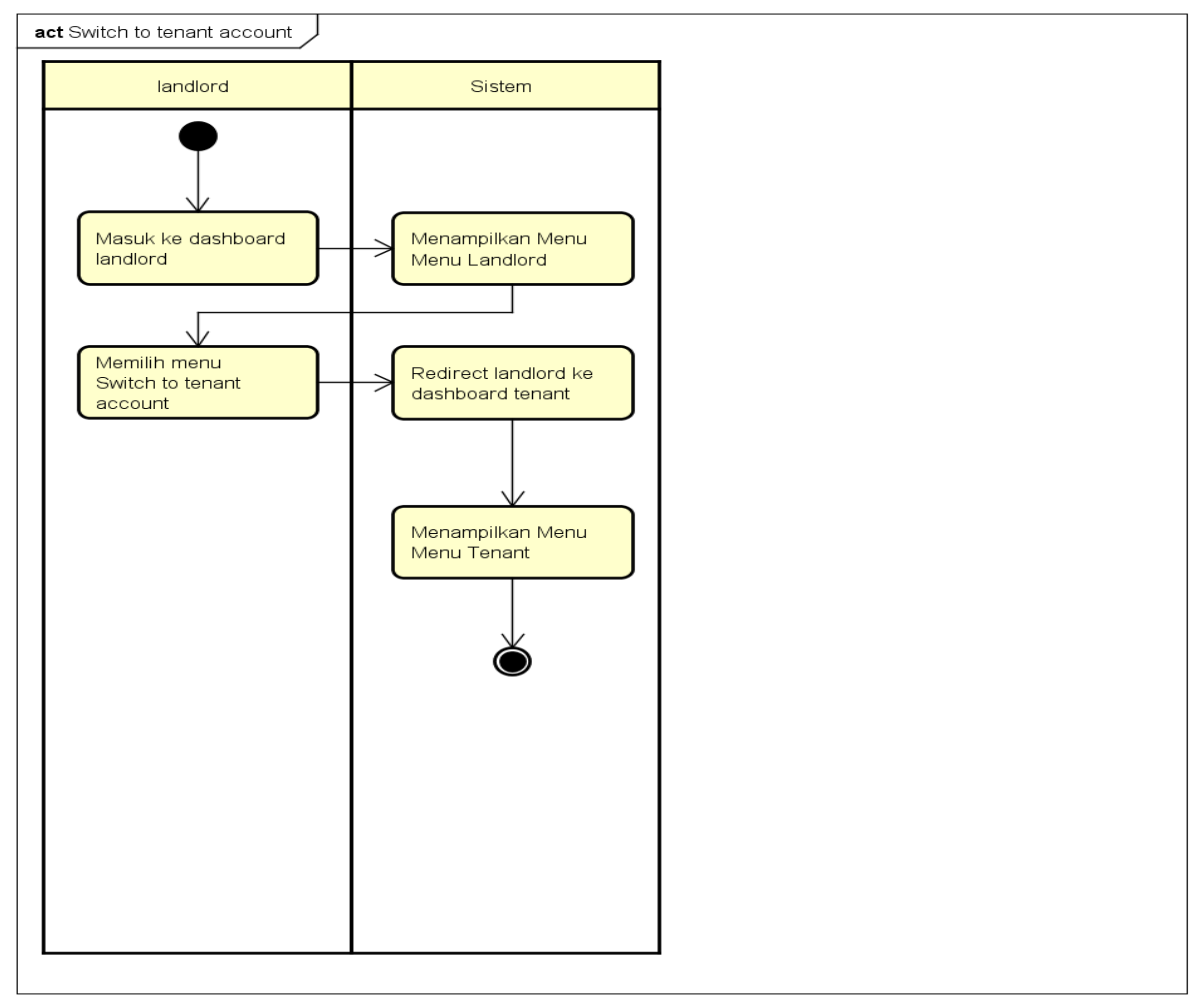

Gambar 3.7 Activity Diagram Switch to Tenant Account 
Analisis dan Perancangan Ulang Sistem Informasi Sewa Apartemen Online

8. Membatalkan Visit Properti(Landlord)

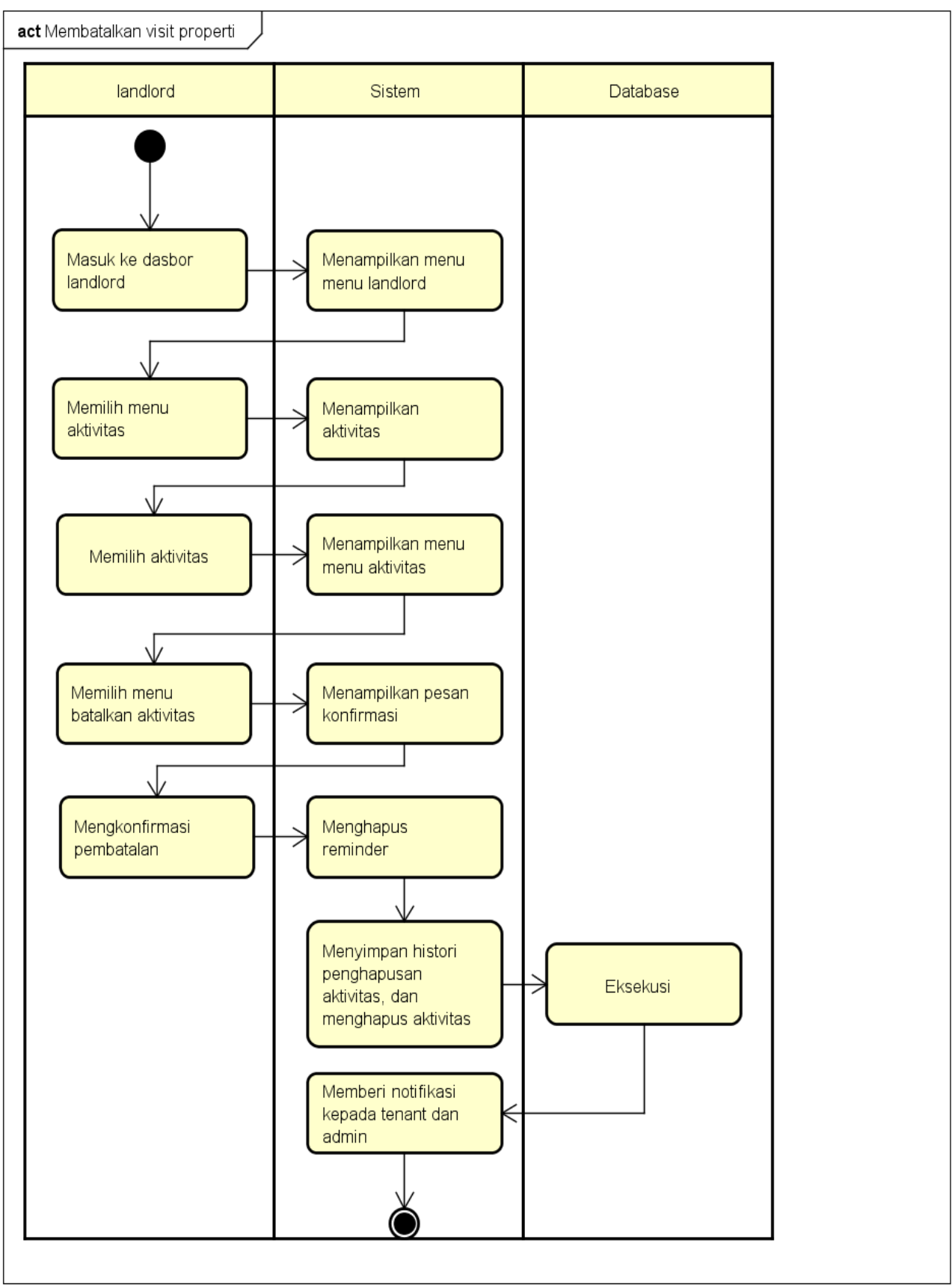

Gambar 3.8 Activity Diagram Membatalkan Visit Properti 
9. Membatalkan Transaksi Sewa Properti(Landlord)

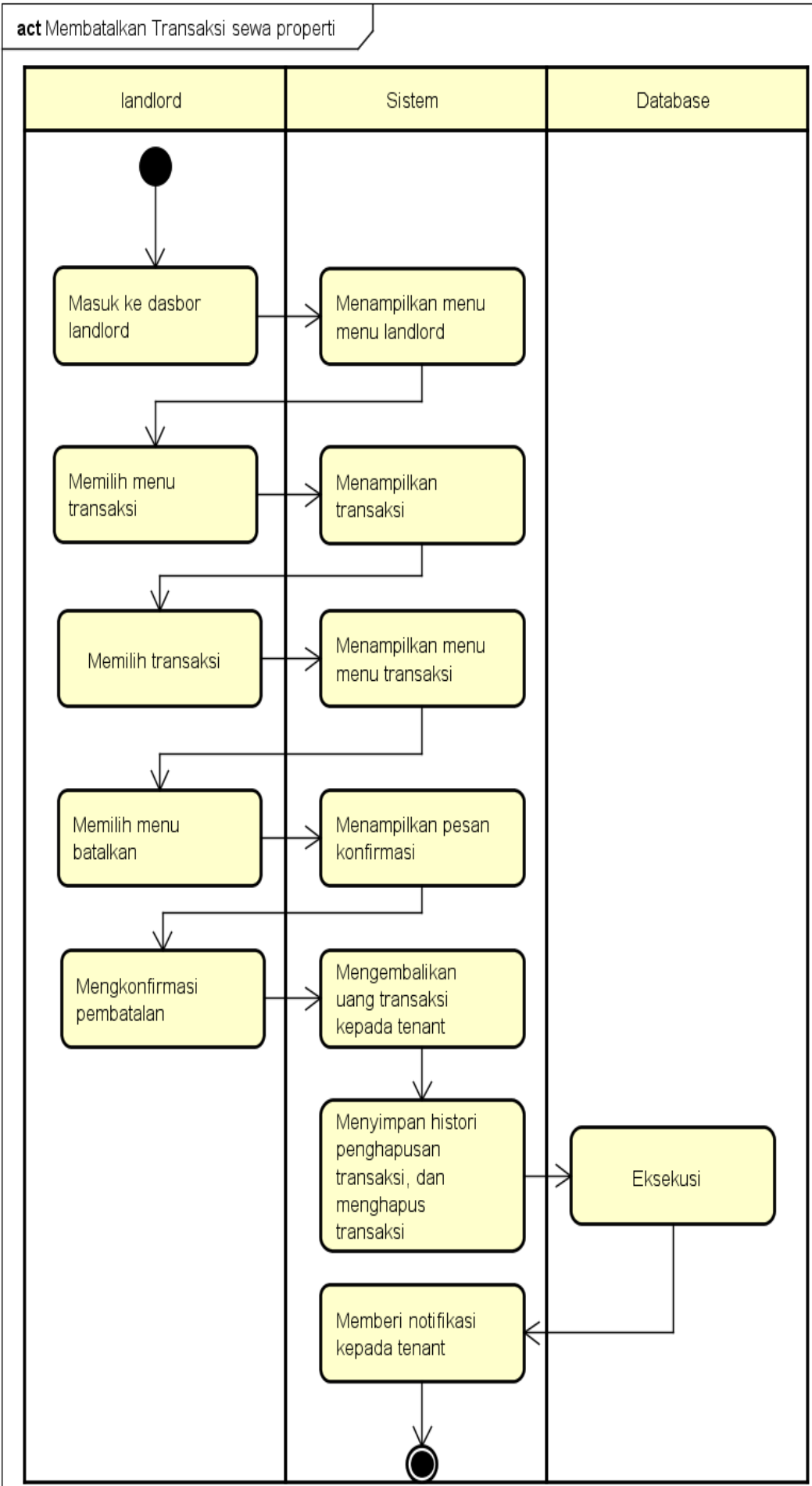

Gambar 3.9 Activity Diagram Membatalkan Transaksi Sewa Properti 
Analisis dan Perancangan Ulang Sistem Informasi Sewa Apartemen Online

10. Mengakses dan Memverifikasi Properti Baru(Admin)

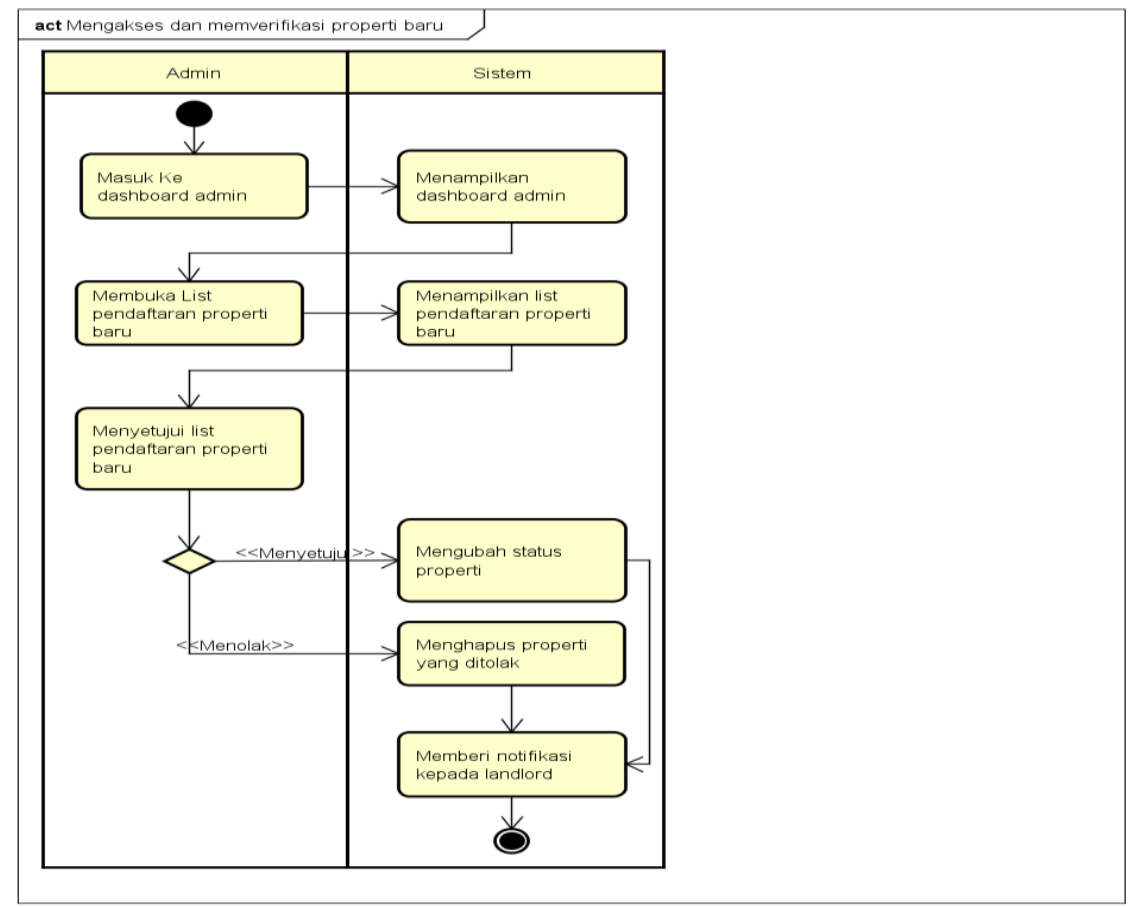

Gambar 3.10 Activity Diagram Mengakses dan Memverifikasi Properti Baru

11. Mengakses dan Memverifikasi Pengajuan Pengiklanan Properti (Admin)

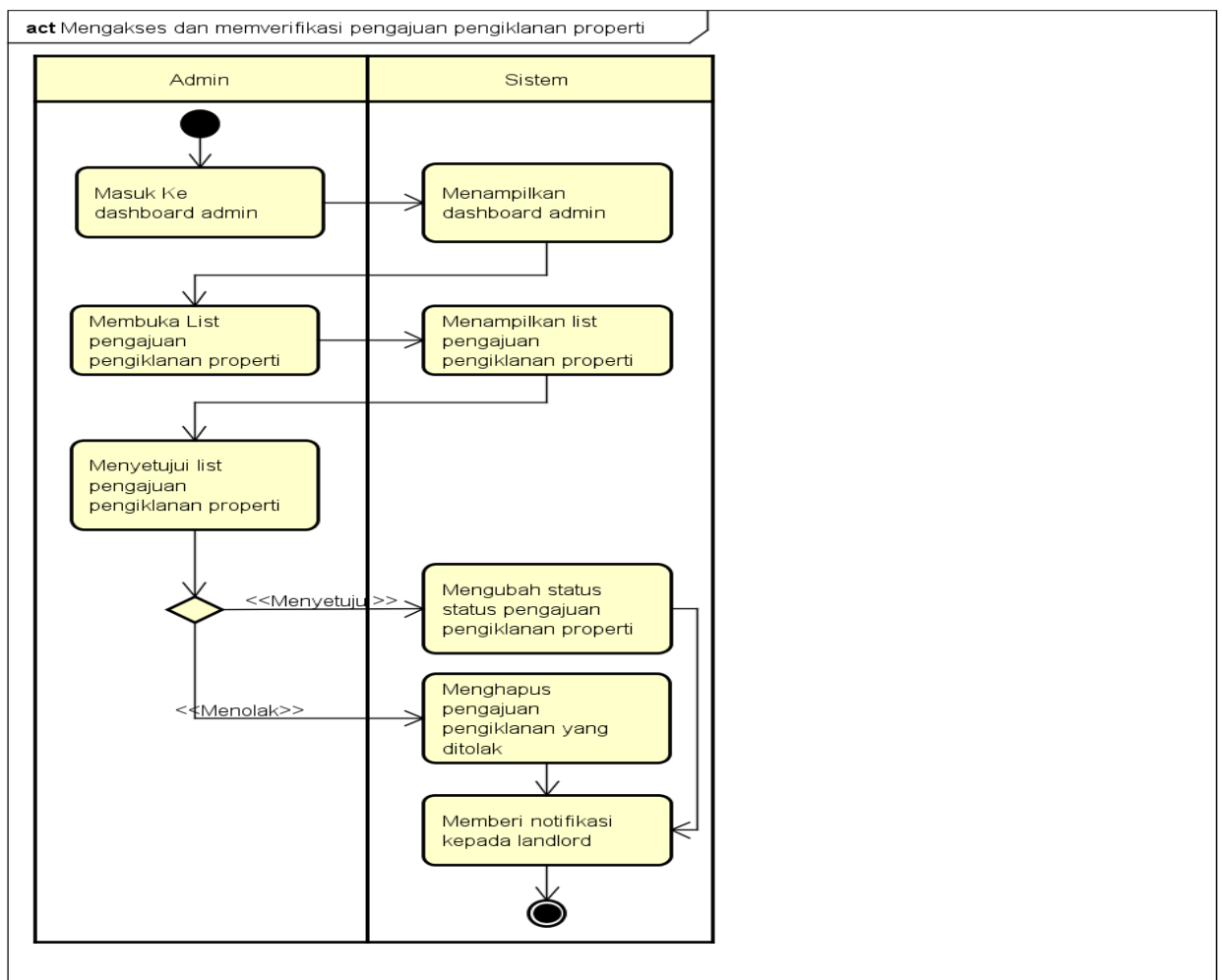

Gambar 3.11 Activity Diagram Mengakses dan Memverifikasi Pengajuan Pengiklanan Properti 
12. Mengakses Timeline Transaksi Akun Tenant(Admin)

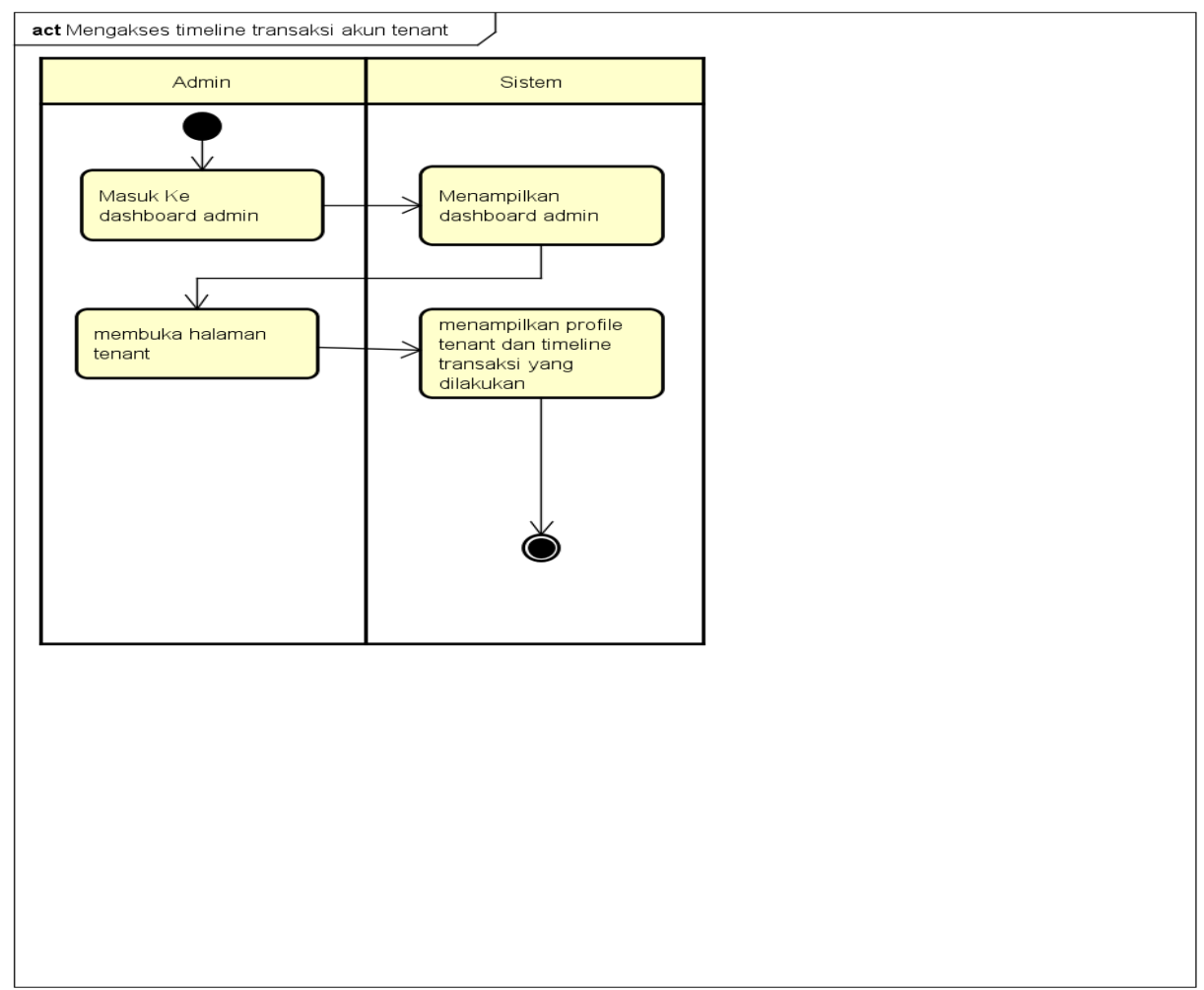

\section{Gambar 3.12 Activity Diagram Mengakses Timeline}

Transaksi Akun Tenant

13. Mengakses List Properti (Tenant)

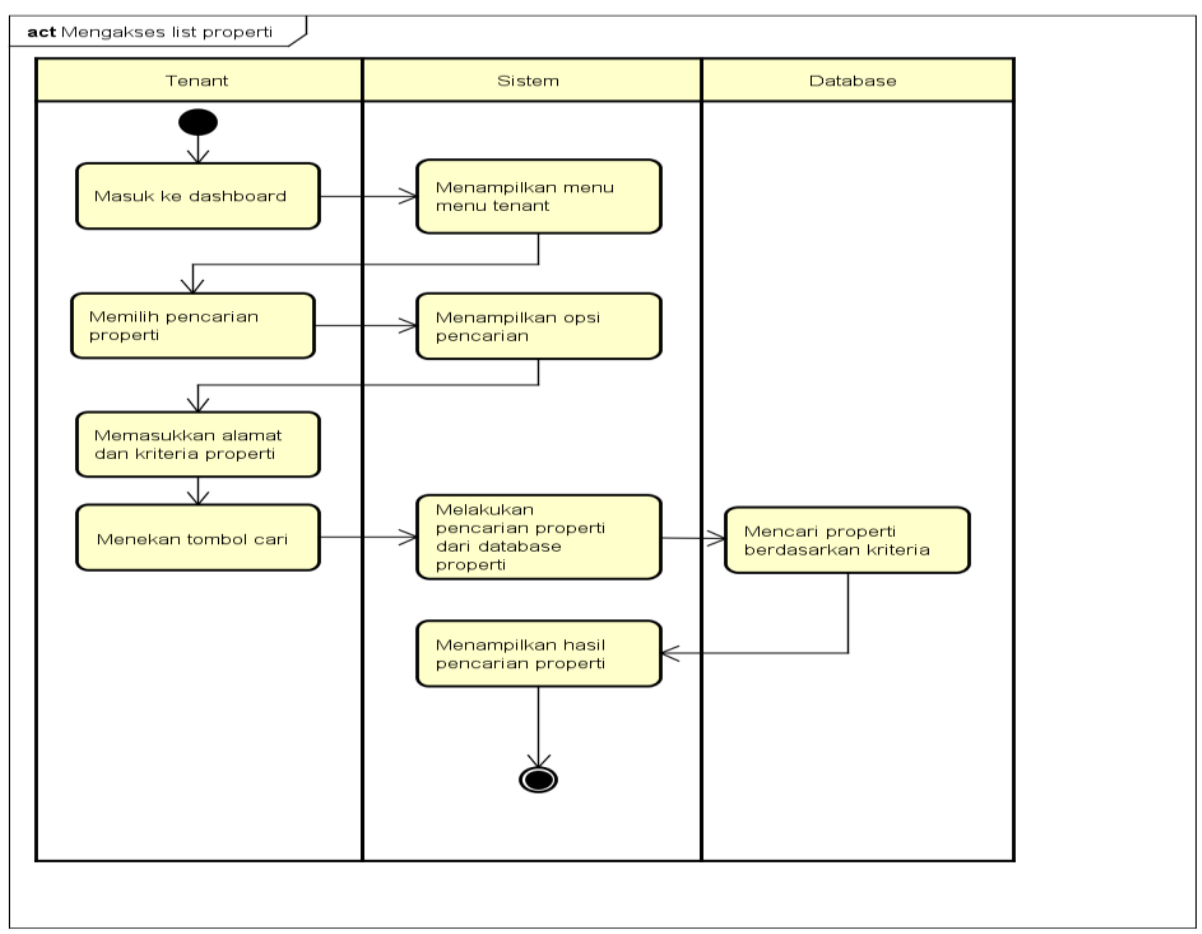

Gambar 3.13 Activity Diagram Mengakses List Properti 
Analisis dan Perancangan Ulang Sistem Informasi Sewa Apartemen Online

14. Menambah Properti ke Daftar Tersimpan(Tenant)

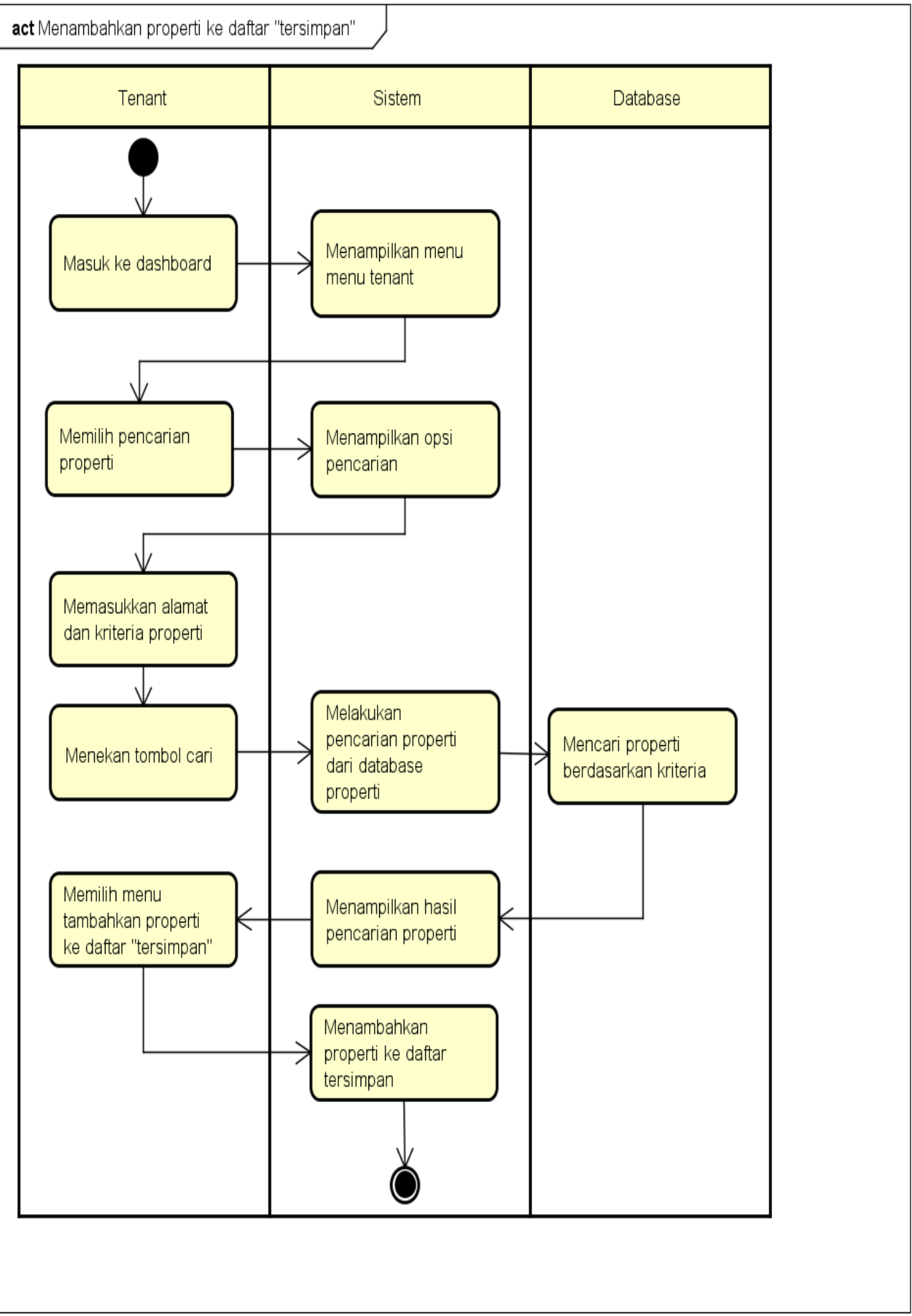

Gambar 3.14 Activity Diagram Menambah Properti ke Daftar Tersimpan 
15. Schedule a Visit(Tenant)

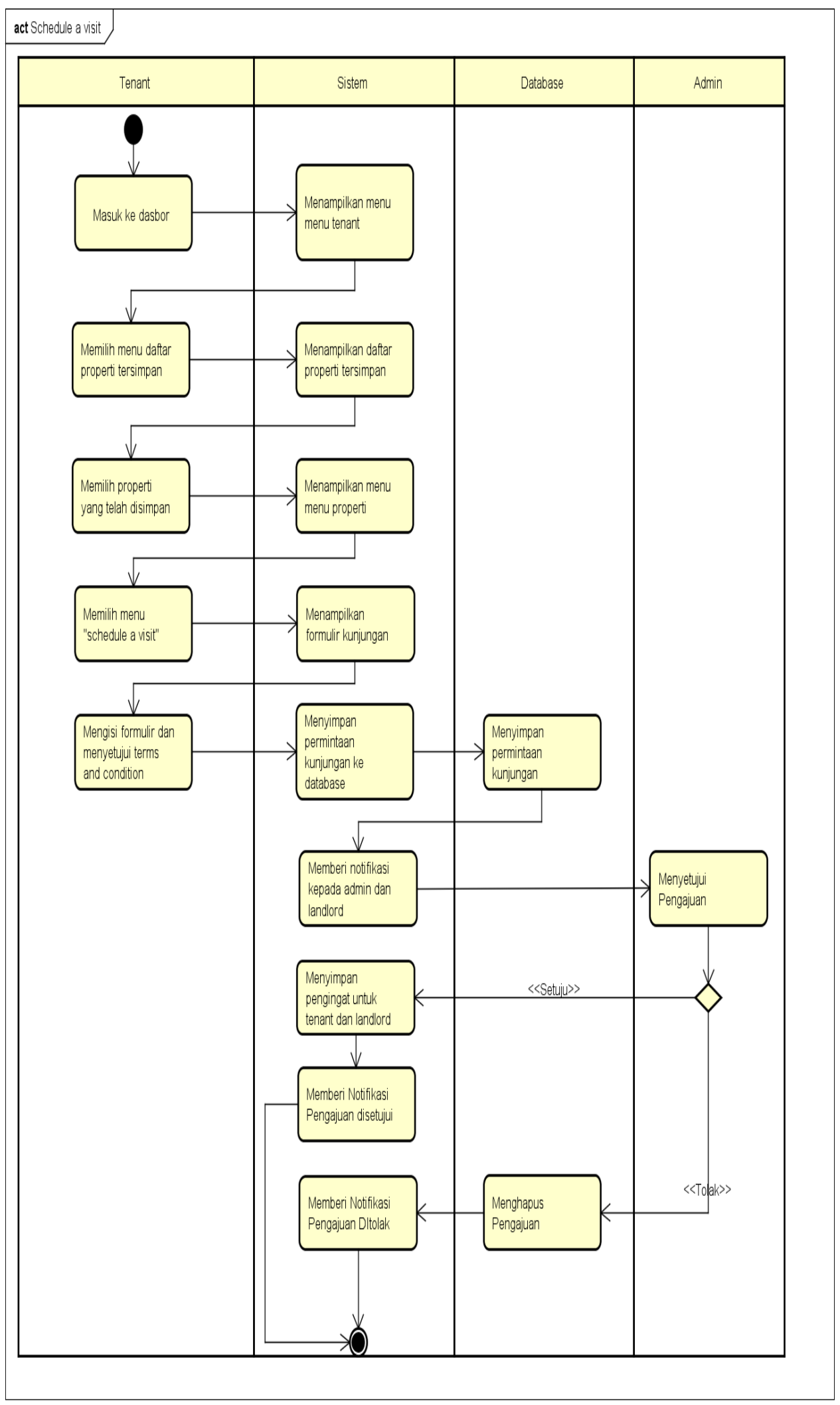

Gambar 3.15 Activity Diagram Schedule a Visit 
Analisis dan Perancangan Ulang Sistem Informasi Sewa Apartemen Online

16. Menyewa Properti(Tenant)

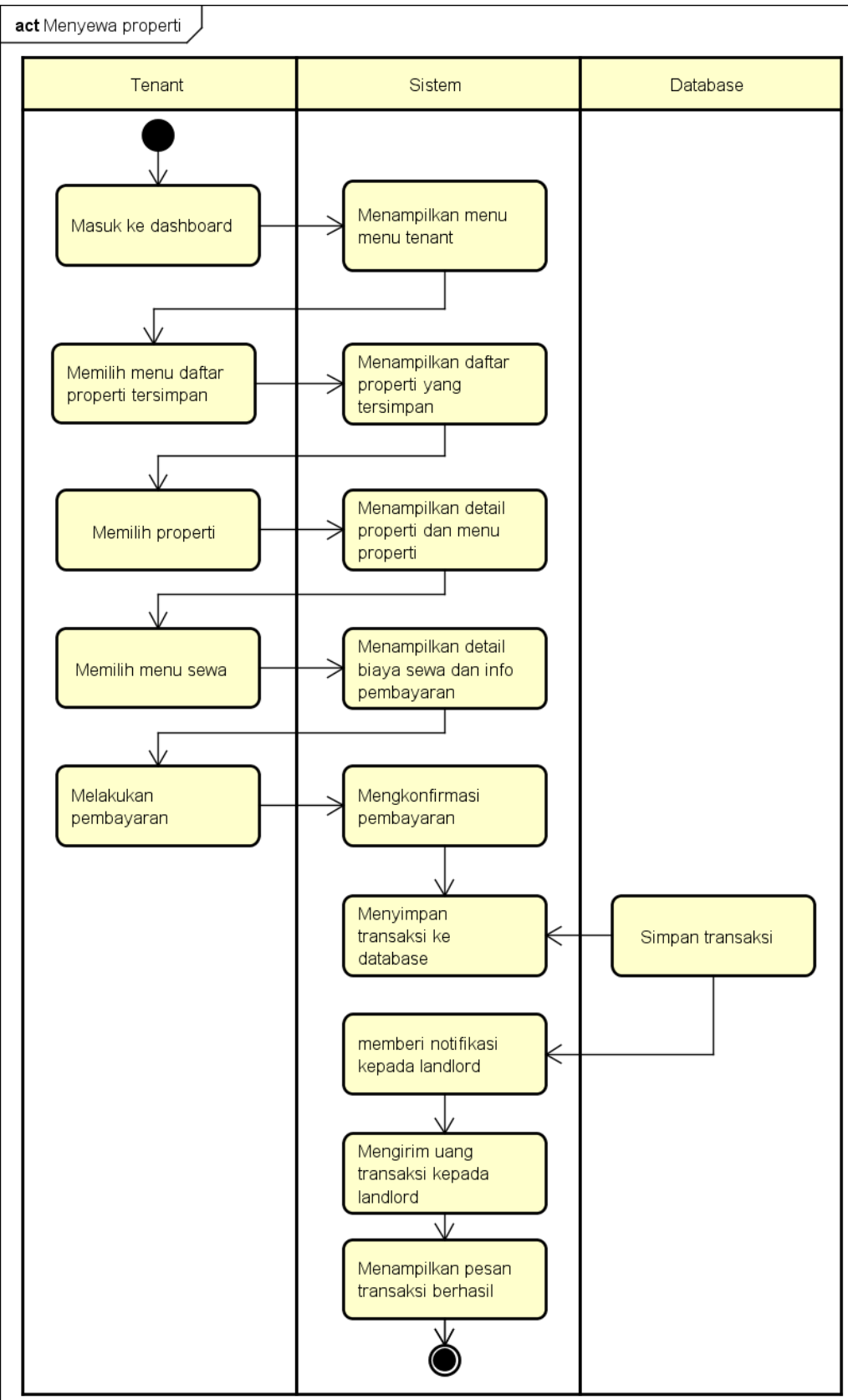

Gambar 3.16 Activity Diagram Menyewa Properti 
Ponsen Sindu Prawito dan Fevy Mardhipta Trista Asri

17. Switch To Landlord Account (Tenant)

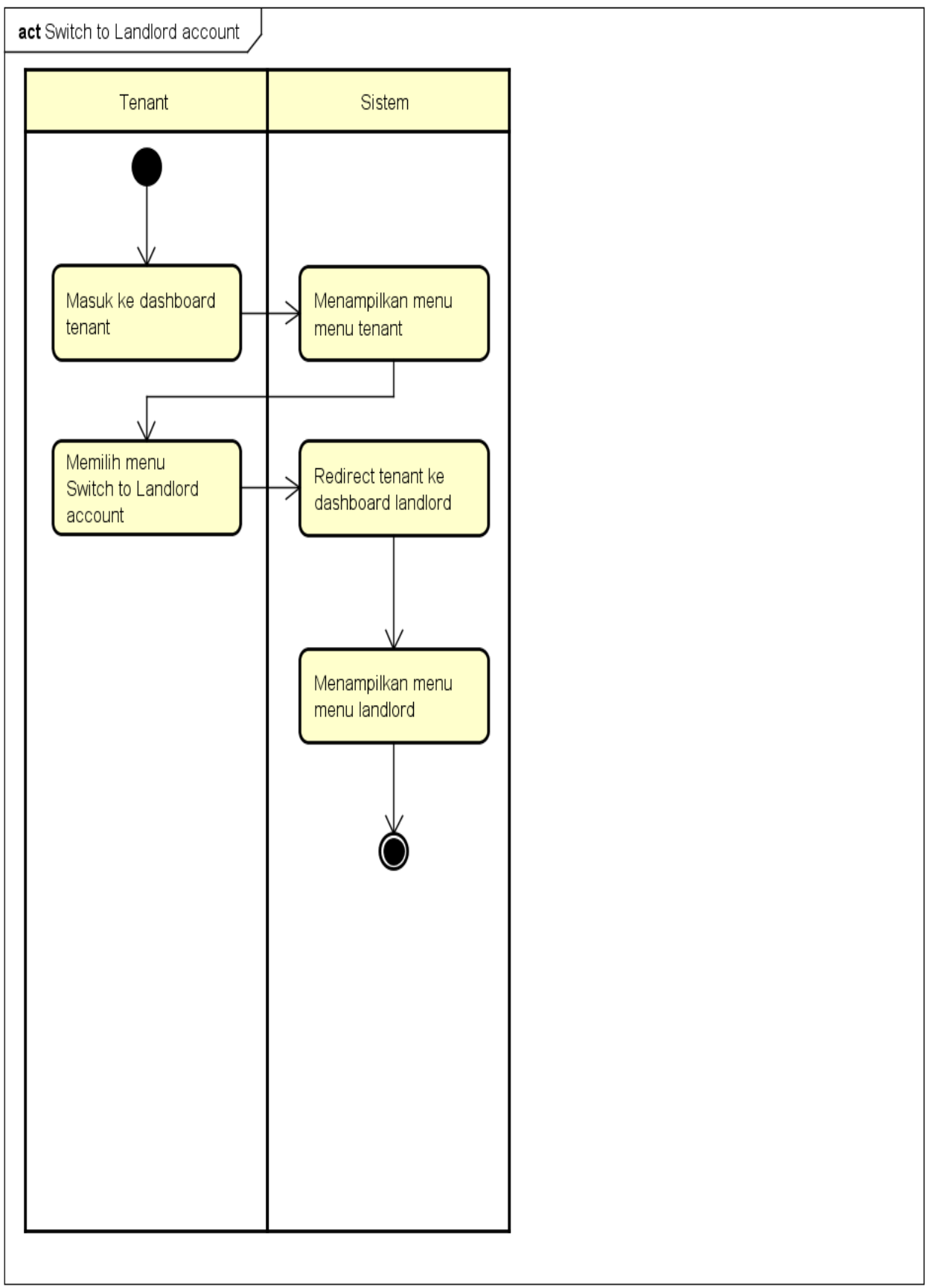

Gambar 3.17 Activity Diagram Switch To Landlord Account 


\section{Kesimpulan}

Berdasarkan hasil analisis dan perancangan dari sistem yang telah dilakukan penulis, maka penulis mengambil kesimpulan, yaitu :

1. Yang menyebabkan sistem yang sedang berjalan menjadi rumit dan sulit dipahami adalah terlalu banyaknya pengajuan dan perbedaan tipe user yang tidak perlu yang akan membuat proses tersebut menjadi terlalu rumit jika digunakan untuk user yang merupakan kalangan mahasiswa dan masyarakat umum.

2. Hal yang membuat sistem yang sedang berjalan menjadi tidak efisien dan memakan waktu adalah pembedaan tipe akun tenant dan banyaknya dokumen yang harus dicek secara manual juga pengkonfirmasian langsung kepada perusahaan terkait sebelum proses verifikasi akun tenant tersebut.

3. Hambatan utama bagi tenant pada saat melakukan transaksi adalah proses yang berbelit-belit dan pelemparan pengajuan dari user regular ke user master. 


\section{BIBLIOGRAFI}

Algra dkk, (1983), Kamus Istilah Hukum Fockema Andereane Belanda-Indonesia, Binacipta, Bandung.

Ardhana, YM Kusuma, (2012), Menyelesaikan Website 30 Juta!, Jasakom, Jakarta.

Asropudin, pipin, (2013), Kamus Teknologi Informasi Komunikasi, Titian Ilmu Bandung, Bandung.

Connolly, T. dan Begg, C., (2015), Database Systems: A Practical Approach to Design, Implementation, and Management, 6th Edition, Pearson, Massachusetts.

Kadir, Abdul, (2014), Pengenalan Sistem Informasi Edisi Revisi, Andi Offset, Yogyakarta.

Ladjamudin, Al-Bahra Bin, (2013), Analisis dan Desain Sistem Informasi, Graha Ilmu, Yogyakarta.

Mulyani, Sri, (2016), Metode Analisis dan Perancangan Sistem, Abdi SisteMatika, Bandung.

Prasetyo, Adi, (2014), Buku Sakti Webmaster,Media Kita, Jakarta Selatan.

Pressman, R.S, (2015), Rekayasa Perangkat Lunak: Pendekatan Praktisi Buku I, Andi, Yogyakarta.

Priyadi, M.T., Yudi, (2014). Kolaborasi SQL dan ERD dalam Implementasi Database. Andi, Yogyakarta.

Raharjo, Budi, dkk., (2012), Modul Pemrograman Web HTML, PHP \& MySQL, Modula, Bandung.

Saputra, Agus, (2013), Menyelesaikan Website 12 Juta secara Professional,PT. Elex Media Komputindo, Jakarta.

Sibero, Alexander F.K. (2012), Kitab Suci Web Programing,Mediakom, Jakarta.

Subhan, Mohamad, (2012), Analisa Perancangan Sistem, Lentera Ilmu Cendikia, Jakarta.

Sugiyanto, (2013), Metode Penelitian Manajemen, Alfabeta, Bandung.

Sugiyono, (2014), Metode Penelitian Pendidikan Pendekatan Kuantitatif, Kualitatif, dan R\&D, Alfabeta, Bandung.

Sukamto, R. A., dan Salahuddin, M., (2013), Rekayasa Perangkat Lunak, Informatika, Bandung. 
Sukamto, R. A., dan Salahuddin, M., (2014), Rekayasa Perangkat Lunak Terstruktur dan Berorientasi Objek, Informatika, Bandung.

Sutabri, Tata, (2012), Analisis Sistem Informasi, Andi, Yogyakarta.

Sutarman, (2012), Buku Pengantar Teknologi Informasi,Bumi Aksara, Jakarta.

Tantra, Rudy, (2012), Manajemen Proyek Sistem Informasi, bagaimana mengolah proyek sistem informasi secara efektif \& efisien:, Andi Offset, Yogyakarta.

Taufiq, (2013), Sistem Informasi Manajemen Konsep Dasar, Analisis dan Metode Pengembangan, Graha Ilmu, Yogyakarta. 